\title{
Review
}

Digestion

\section{Delicate Balance of Bleeding and Thrombosis in End-Stage Liver Disease and Liver Transplantation}

\author{
Fuat Hakan Saner ${ }^{a}$ Robert K. Gieseler ${ }^{\text {b, d }}$ Hikmet Akız $^{f}$ Ali Canbay $^{b}$ \\ Klaus Görlinger ${ }^{c, e}$ \\ ${ }^{a}$ Department of General, Visceral and Transplantation Surgery, ${ }^{b}$ Department of Gastroenterology and Hepatology, \\ and 'Anesthesiology and Intensive Care Medicine, University Hospital Essen, University of Duisburg-Essen, Essen, \\ ${ }^{d}$ Rodos BioTarget GmbH, Medical Park Hannover, Hannover, and eTem International GmbH, Munich, Germany; \\ fGastroenterology and Hepatology, Çukorova University, Adana, Turkey
}

\section{Key Words}

Bleeding risk - End-stage liver disease $\cdot$ Hepatic

coagulopathy · Hepatitis C treatment · Liver

transplantation - Thromboprophylaxis - Thrombosis .

Whole-blood coagulation

\begin{abstract}
Liver transplantation in cirrhotic patients is accompanied by severe bleeding. Indeed, the first 100 recipients of liver allografts transplanted by Thomas E. Starzl died mainly by uncontrolled bleeding. Since then, much progress has been made as to the understanding of the pathophysiology and the treatment of hemostatic disorders in cirrhotic patients. The aim of this review is to provide a state-of-the-art overview on recent developments and treatment options for hemostatic disorder in cirrhotic patients. Patients with endstage-liver disease (ESLD) do not suffer only from procoagulant deficiency; there is also a lack of natural anticoagulants (i.e. proteins $\mathrm{C}$ and $\mathrm{S}$ ) and profibrinolytics. Conventional laboratory methods such as the determination of the international normalized ratio or the activated partial thromboplastin time cannot predict bleeding complications in these patients. Progressive diagnostic techniques reveal that cir-
\end{abstract}

rhotic patients have the same capacity to produce thrombin like healthy volunteers. Moreover, cirrhotic patients - and particularly those with primary biliary cirrhosis or primary sclerosing cholangitis - are at a higher risk for developing thrombosis as compared with healthy controls. Hemostatic alterations are common in cirrhotic patients; they involve both the pro- and the anticoagulant pathways. However, this is a very delicate balance, which may be shifted to either of these pathways by different treatments thereby causing bleeding or thrombosis, respectively.

Copyright $\odot 2013$ S. Karger AG, Basel

\section{Introduction}

Liver transplantation is a life-saving procedure in acute and chronic liver failure. The first 100 liver transplantations were associated with high mortality, while most of the patients died from uncontrolled bleeding [1]. The literature in the recent 10 years indicated that transfused blood products (red packed cells (RBCs), fresh frozen plasma (FFP) and platelets) were associated with increased morbidity and mortality [2-5]. The main confounding factors for bleeding include coagulation

\section{KARGER}

E-Mail karger@karger.com www.karger.com/dig
(C) 2013 S. Karger AG, Basel

$0012-2823 / 13 / 0883-0135 \$ 38.00 / 0$
Fuat Hakan Saner, MD

Department of General, Visceral and Transplantation Surgery

University Hospital Essen

Hufelandstrasse 55, DE-45122 Essen (Germany)

E-Mail fuat.saner@uni-due.de 
abnormalities depending on the type of preexisting liver disease and hyperfibrinolysis, particularly after reperfusion $[6,7]$. Advances in the understanding of the pathophysiology of coagulation and in the improvement of surgical skills, the introduction of specific techniques as well as point-of-care diagnostics and specific treatments have resulted in the significant reduction of blood loss $[8,9]$. However, in some patients with end-stage liver disease (ESLD) the risk to develop thrombosis is higher than to develop bleeding. This is for example the case in patients with cholestatic cirrhosis (e.g. primary sclerosing cholangitis and primary biliary cirrhosis) [10].

\section{Pathophysiology of Hepatic Coagulopathy in Liver Diseases}

Bleeding is a common problem in patients with liver diseases as it is due to a hemostatic defect in cirrhosis or in acute liver failure, respectively $[11,12]$. However, these findings have been challenged recently. Indeed, there are major changes in the hemostatic system, including endothelial function, platelet counts, pro- and anticoagulants, which results in a new balance, but not so stable as in healthy volunteers. The balance may shift to both sides thrombosis or bleeding. The impaired production of coagulation factors and thrombocytopenia might be counteracted by upregulated von Willebrand factor (vWF), which is mainly produced by and released from the endothelium [13], which improves the adhesion of the platelets and the endothelium. Coagulation factor levels - in particular the vitamin K-dependent factors (II, VII, IX and $\mathrm{X}$ ) as well factor $\mathrm{V}$ - are reduced, while factor VIII is usually increased [14]. In stable and uncompensated cirrhosis, fibrinogen concentrations are in the reference range, but they are significantly decreased in the advanced stage of disease. Recent publications indicate that dysfibrinogenemia were associated with significantly higher sialic acid levels than controls or patients with normal fibrin polymerization [15] (fig. 1).

However, many of these effects are compensated by different mechanisms. The most important anticoagulants - proteins $\mathrm{C}$ and $\mathrm{S}$ - are also vitamin $\mathrm{K}$-dependent and decreased in ESLD. Tissue factor pathway inhibitor, which is mainly synthesized by endothelial cells may also be decreased in advance liver cirrhosis [16].

Reduced levels of plasminogen and antiplasmin $\left(\alpha_{2^{-}}\right.$ antiplasmin; $\alpha_{2}$-AP), thrombin-activatable fibrinolysis inhibitor and factor XIII were reported both for ESLD and for acute liver failure. This is counterbalanced by the

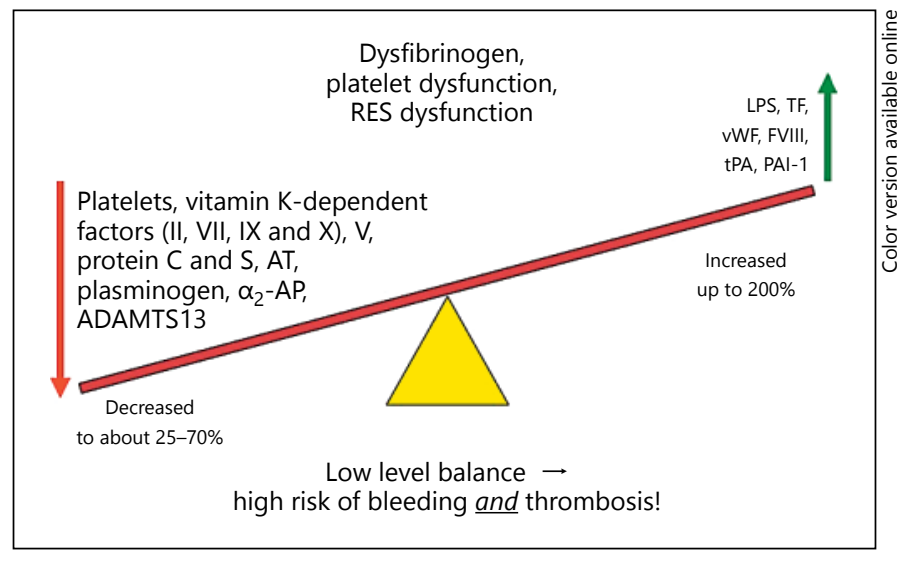

Fig. 1. Hemostatic dysbalance in patients with ESLD. AT = Antithrombin; LPS = lipopolysaccharides; RES = reticuloendothelial system.

enhanced release and reduced hepatic clearance of tissue plasminogen activator (tPA). Plasminogen activator inhibitor 1 (PAI-1) is also increased, yet not to the same extent [17]. The final effect was described as hyperfibrinolysis [18]. While this conclusion remains controversial, hyperfibrinolysis was confirmed in a recent study for up to $46 \%$ of patients suffering from liver cirrhosis [19]. In liver transplant settings, hyperfibrinolysis may occur in up to $60 \%$ of the cases, where one third of these cases are self-limiting without antifibrinolytic treatment [20].

\section{Conventional Coagulation Testing and Bleeding Risk in ESLD}

Bleeding risk assessment is imperative in ESLD patients before any intervention is considered, in particular prior to transplantation. However, conventional coagulation tests such as for the international normalized ratio (INR) or the activated partial thromboplastin time (aPTT) only poorly reflect the pathophysiological changes in advanced liver cirrhosis reported above [21,22]. Patients in advanced stages of liver disease develop thrombosis despite pathological procoagulation profiles. Still, INR and aPTT are predictive for procoagulation factor deficiency, but they are not sensitive for decreased protein $\mathrm{C}$ and $\mathrm{S}$ activity. In case of hepatic coagulopathy, both the vitamin $\mathrm{K}$-dependent procoagulant factors II, VII, IX and X as well as the anticoagulant system (proteins $\mathrm{C}$ and $\mathrm{S}$ ) are affected, which maintains the balance between pro- and anticoagulant factors, but not stable as compared with healthy persons. Addition of thrombomodulin allows for 
assessing the endogenous thrombin potential under consideration of both systems, which correlates much better with bleeding prediction than conventional laboratory testing $[21,22]$. Interestingly, in case of decreased levels of protein $\mathrm{C}$ and protein $\mathrm{S}$, patients with only mild liver dysfunction (model for end-stage liver disease (MELD) score $<20$ ) appear to be at a higher risk for developing thrombosis than bleeding [23]. Intriguingly, a study from 1997 indicates that patients with cholestatic cirrhosis are in a hypercoagulable state [24]. Furthermore, vitamin Kdependent factors and factors I, V and XIII are decreased in cirrhotic patients, whereas $\mathrm{vWF}$ and factor VIII, which are mainly produced and released by the endothelium were significantly elevated $[13,23]$. This may explain the increased clotting strength, even in patients with thrombocytopenia [13].

\section{Whole-Blood Coagulation and Testing of Platelet Function}

The best method to reflect the interaction between plasmatic and cellular components of hemostasis seems to be viscoelastic testing using whole blood - such as thromboelastometry/graphy (ROTEM ${ }^{\mathrm{TM}}$; Tem International, Munich, Germany, or TEG ${ }^{\mathrm{TM}}$, Haemonetics, Niles, Ill., USA) [25, 26]. Moreover, this method can also be used for the reliable and timely detection of hypofibrinogenemia and hyperfibrinolysis [27, 28]. An increased maximum clot firmness (MCF) or maximum amplitude in ROTEM ${ }^{\mathrm{TM}}$ or $\mathrm{TEG}^{\mathrm{TM}}$, respectively, reflects hypercoagulability and is predictive for postoperative thromboembolic events [29,30]. Platelet dysfunction can be reliably assessed at the bedside by whole-blood impedance aggregometry (Multiplate ${ }^{\mathrm{TM}}$; Roche Diagnostics, Mannheim, Germany) [31, 32]. The interpretation of platelet function is however limited to a platelet count $<50,000 / \mu \mathrm{l}[33]$.

\section{Management of Hepatic Coagulopathy}

Hemostatic interventions should be focused on bleeding patients and not just to correct laboratory results [34, 35]. The actual main indication for using FFP transfusions is plasma exchange [34]. In contrast, the use of FFP for coagulation management arose from the fact that FFP contains both pro- and anticoagulants in a 'balanced' ratio. However, this potential advantage cannot be applied to the pathophysiology of hepatic coagulopathy. Indeed, the vitamin $\mathrm{K}$-dependent factors II, VII, IX and X as well as the vitamin $\mathrm{K}$-dependent anticoagulant proteins $\mathrm{C}$ and $\mathrm{S}$ are decreased [12]. In addition, fibrinogen and factor $\mathrm{V}$ levels are decreased, while factor VIII and vWF are tremendously elevated to up to $200 \%$ of the reference value means $[13,36]$. However, the fibrinogen concentration in FFP is at a low level of just about $2 \mathrm{~g} / \mathrm{l}$. Therefore, huge amounts of FFP would be required to increase the fibrinogen plasma concentration as well as the activity of the vitamin $\mathrm{K}$-dependent pro- and anticoagulants. It has to be considered that FFP also contains factor VIII and vWF, whereas the application of these factors are counterindicated in patients with already elevated serum levels of factor VIII and vWF. Therefore, FFP transfusion may in this setting lead to thrombosis. Furthermore, the use of solvent/detergent is associated for both thrombosis or augmented hyperfibrinolysis.

In order to decrease the content of protein $S$ there is an increased risk for thrombosis [37] or hyperfibrinolysis may be augmented due to a decreased content of $\alpha_{2}$-AP [38]. Approximately $30 \%$ of the fibrinogen is also affected and destroyed [39] during methylene blue pathogen inactivation, which results in reduced fibrin polymerization and again impairs the efficacy of FFP. It should be considered that the transfusion of more than 4 units of FFP is associated with an increased risk for acute lung injury and in case of living donation and small-for-size syndrome an increased rate of hepatic artery thrombosis is reported [3, 40, 41]. Sarani et al. [42] pointed out that the use of FFP is associated with a 3 -fold increase in the incidence of nosocomial infections compared to patients without FFP transfusion. These data suggest the use of factor concentrates instead FFP for coagulation management $[40,43,44]$. However, the use of factor concentrates should be guided by point-of-care testing such as by ROTEM $^{\mathrm{TM}}$ (fig. 2-5) or TEG ${ }^{\mathrm{TM}}[20]$.

This kind of coagulation monitoring enables a calculated and targeted coagulation management in patients with ESLD using four-factor prothrombin complex concentrates (PCCs, e.g. Beriplex: CSL Behring GmbH, Marburg, Germany, or Octaplex: Octapharma AG, Lachen, Switzerland), which contain coagulation factors II, VII, IX, and $\mathrm{X}$ as well as proteins $\mathrm{C}$ and $\mathrm{S}$. The replacement of vitamin K-dependent coagulation factors in patients with ESLD differs from the reversal of oral vitamin $\mathrm{K}$ antagonists. Patients with vitamin $\mathrm{K}$ antagonists require $1 \mathrm{IU} / \mathrm{kg}$ PCC to increase the prothrombin time (PT) time by $1 \%$, while patients with ESLD require $1.6 \mathrm{IU} / \mathrm{kg}$ to achieve the same increase $[45,46]$. Due to the balanced content of proand anticoagulant vitamin K-dependent factors (II, VII, 
Fig. 2. Thrombelastography with the most important values and contribution of platelets and fibrinogen to the clot strength. Clotting time (CT) indicates time from start of measurement until initiation of clotting. MCF = Maximum clot firmness; A10 = amplitude of the clot strength after 10 min allows to assess for the MCF after $10 \mathrm{~min} ; \mathrm{LI}=$ lysis index, reduction of the clot firmness after the MCF in relation to the MCF.
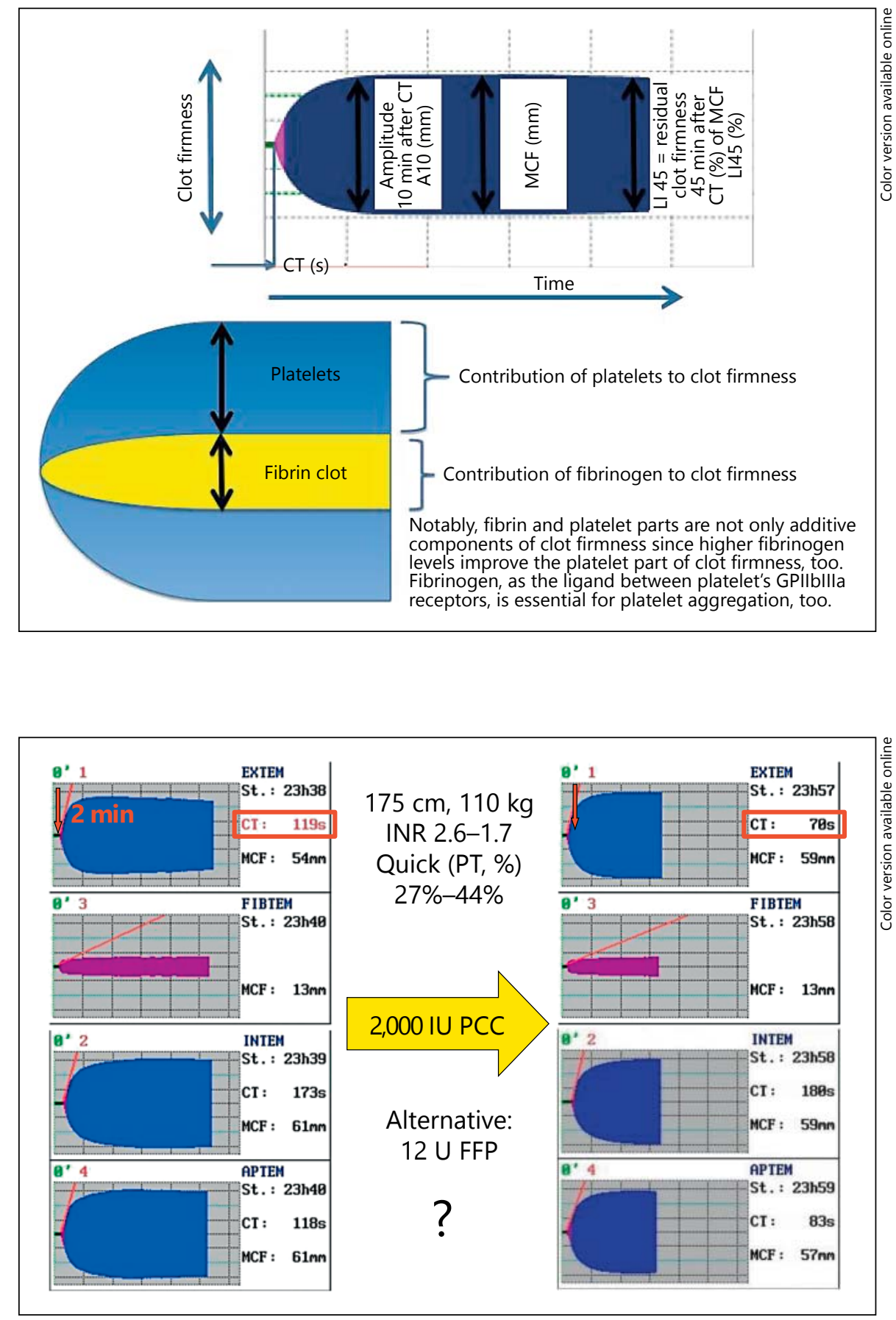

Fig. 3. Deficiency of vitamin K-dependent factors and calculated therapy with fourfactor PCC. The EXTEM and FIBTEM channels indicate a normal MCF. However, a significantly increased CT in the EXTEM channel indicates a delayed thrombin generation as the cause for bleeding. After replacement with 2,000 IU four-factor PCC, the CT improved whereupon the patients' bleeding ceased. Notably, this diagnosis, treatment and control of treatment were completed within $19 \mathrm{~min}$. The same effect is achieved by the transfusion of 12 units of FFP (cave: volume overload, hemodilution with $\mathrm{RBC}$ transfusion requirement). $\mathrm{CT}=$ Clotting time; Quick = activity in \% of normal as based on the PT; St. = starting time of the test; $\mathrm{U}=$ unit.
IX, $\mathrm{X}$ and protein $\mathrm{C}$ and S), the incidence of thromboembolic events associated with the calculated targeted therapy with these PCCs is quite low [45]. Recently, the incidence of thromboembolic events in 495 patients was shown to be $4 \%$ [47]. In 266 liver-transplanted patients, our own data revealed an incidence of pulmonary embolism of only $1.1 \%$. Furthermore, the use of platelets, FFP, and packed
RBCs was significantly lower compared to the requirements in previous studies [48]. The main difference between both studies however was the coagulation management. Indeed, while Sakai et al. [47] preferred a FFP- and platelet-based approach, the coagulation management in our center was based on the first-line use of fibrinogen and PCC as guided by thromboelastometry. Thus, in order to 
Fig. 4. Fibrinogen deficiency and calculated therapy with fibrinogen concentrate. This figure illustrates a bleeding patient due to acquired hypofibrinogenemia. The EXTEM channel detects a decreased MCF (41 mm, lower limit $50 \mathrm{~mm}$ ), mainly caused by fibrinogen deficiency. This is detected in the FIBTEM (MCF $4 \mathrm{~mm}$, lower limit $9 \mathrm{~mm}$ ). After treatment with fibrinogen, the bleeding was stopped and the FIBTEM (FIB) indicated a regular MCF for adequate hemostasis. $\mathrm{CT}=$ Clotting time; St. = starting time of the test.

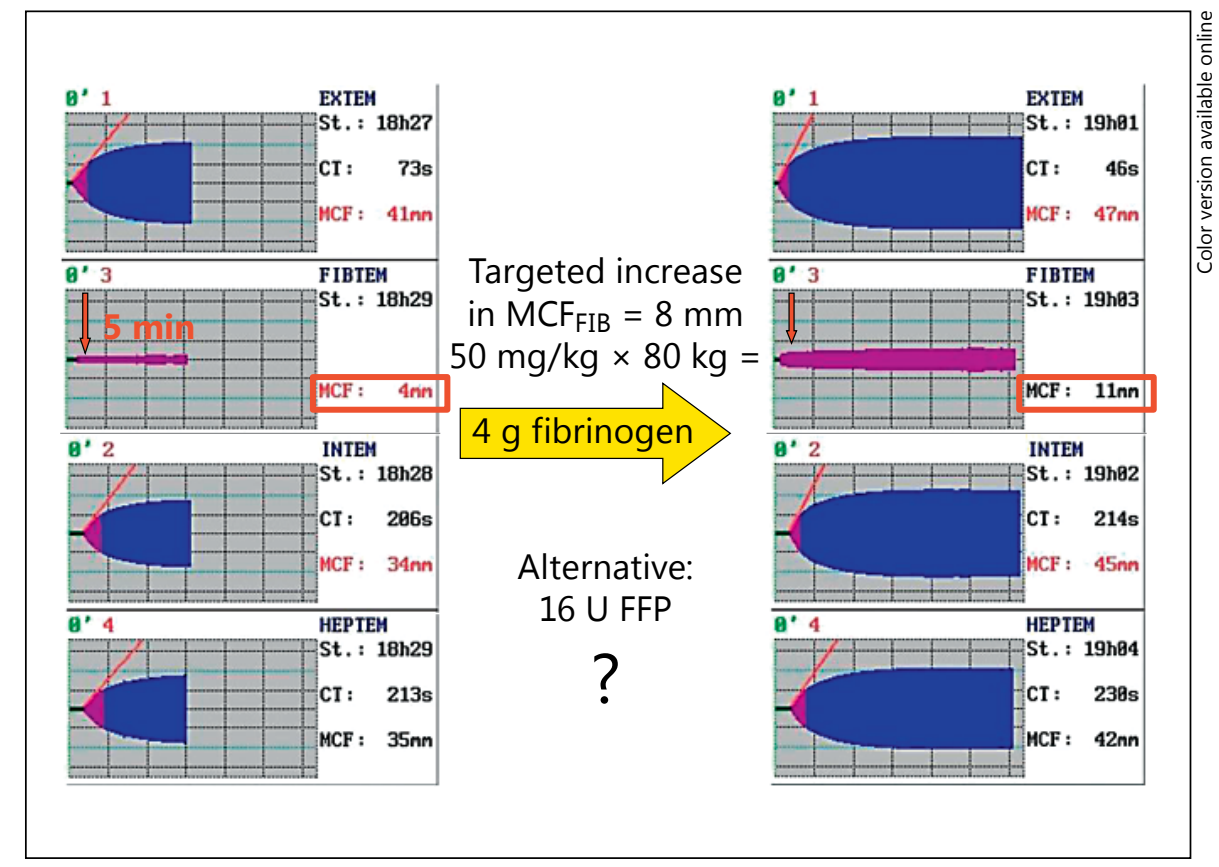

better understand the requirements of coagulation management as well as for the potential stratification of patients, prospective randomized trials are needed.

Activated recombinant factor VII (rFVIIa) is a procoagulant agent, which is approved for the treatment of bleeding in patients with acquired hemophilia A or B. Tissue factor and factor VIIa play key roles in hemostasis [49]. However, while there was initial enthusiasm as to the reduction in blood loss during liver transplantation by using rFVIIa, two large prospective randomized trials failed to confirm this early observation $[50,51]$. In contrast, a distinct trend towards a higher incidence of thromboembolic adverse events was found for the rFVIIa treatment group [50, 51].

Hyperfibrinolysis has been a major issue in liver transplantation over the past three decades, particularly after graft reperfusion $[7,52]$. The use of antifibrinolytic drugs is proven to reduce the blood loss by around $30 \%$ in liver transplant patients $[53,54]$. Despite the demonstrated benefit of these agents, some safety concerns - mainly based on the risk of thrombosis and ischemic events prevent these agents from being employed routinely [55]. However, a meta-analysis including 1,400 liver transplant patients did not be support these concerns as it did not find an increased risk for thrombosis in patients receiving antifibrinolytic therapy [54]. However, in patients undergoing cardiac surgery, the use of aprotinin was found to be associated with a higher risk for postoperative dialysis, kidney failure and mortality $[56,57]$. In a recent study, including 1,043 liver transplant patients, the use of aprotinin was a risk factor for severe renal dysfunction within the first week. Still, no differences in renal function were noted 30 and 365 days, postoperatively. Moreover, there were no significant differences in renal replacement therapy in 1-year patient survival rates with or without aprotinin [58]. Owing to the increased renal dysfunction and mortality in high-risk cardiac surgery, aprotinin was transiently withdrawn from the market. In 2012 however, the European Medicines Agency recommended the suspension of the marketing authorizations for aprotinincontaining medicines in the EU to be lifted [59]. The reason was that the results of the BART study [60] on which the suspension was based were found to be unreliable. In any event, the lysine analogues $\varepsilon$-aminocapronic acid and tranexamic acid can be used as alternatives to aprotinin in patients with hyperfibrinolysis. However, only few studies thus far addressed to prove the benefits of a nonprophylactic use of lysine analogues as a treatment option for hyperfibrinolysis in liver transplantation, and these studies moreover failed to provide clear results [61]. This situation calls for a clear need to conduct a higher number of more sophisticated studies in this setting.

Fibrinogen levels in cirrhotic patients are reduced due to both decreased synthesis and increased turnover. Consequently, there is no postoperative increase in fibrinogen concentrations in patients with ESLD. In contrast, a de- 
creased fibrinogen level, in particular after extended liver resection, has been shown to be predictive for postoperative complications and increased mortality [62]. Several studies have shown that besides a decreased fibrinogen concentration, coagulation is also impaired by dysfibrinogenemia and disorders of fibrin polymerization by fibrin-degrading products and/or infused artificial colloids [63-65]. Additionally, artificial colloids may provoke the generation of false-positive fibrinogen values by optical methods such as the Clauss method [66]. The best and safest treatment option in clinically relevant fibrinogen deficiency is the replacement with fibrinogen concentrate [67-69]; the dosage of the fibrinogen concentrate can be calculated as based on the targeted increase in the plasma fibrinogen concentration or clot firmness as determined by the FIBTEMF (ROTEM ${ }^{\mathrm{TM}}$ ) assay, with the extrinsic activation by recombinant tissue factor and the inhibition of platelet function by cytochalasin $\mathrm{D}$ (Tem International $\mathrm{GmbH}$ ) (table 1). For example, a targeted fibrinogen increase by $1 \mathrm{~g} / \mathrm{l}$ requires the fibrinogen concentrate to be dosed at $50 \mathrm{mg} / \mathrm{kg}$ body weight, which results in an $8-\mathrm{mm}$ increase of the MCF pattern measured by FIBTEMF [67, $70,71]$. The clot strength increases in a fibrinogen concentration-dependent manner and independent of the platelet count. It is crucial to maintain the fibrinogen concentration in the normal range in the presence of thrombocytopenia so as to avoid bleeding [25].

In the absence of signs of clinically relevant bleeding due to severe thrombocytopenia or platelet dysfunction, transfusion of platelets should strictly be avoided. Indeed, recent data clearly demonstrated that platelet transfusion during liver transplantation is associated with a significantly increased 1-year mortality ( 26 vs. $8 \%$ ) due to acute lung injury, independent from RBC transfusion $[4,72]$. Hemovigilance data indicate that platelet transfusion has the highest risk for bacterial contamination with consecutive sepsis in the transfused recipient among all allogeneic blood products [73]. For a suggestion on the coagulation algorithm, see figure 4 .

Factor XIII plays a pivotal role at the end of the coagulation cascade. It promotes the cross-linking of the fibrin polymers and by binding with its subunit A provides a stable fibrin clot that is protected from fibrinolysis $[74,75]$.

Increased soluble fibrin monomers and decreased factor XIII activity were found among elective surgical patients with unexpected bleeding [76]. In patients with a factor XIII activity of $\leq 60 \%$ undergoing neurosurgery the relative risk of developing a postoperative hematoma was 6.4 -fold. The risk increased 12 -fold, when serum fibrinogen level was $<1.5 \mathrm{~g} / 1$ [77]. Standard laboratory coagula-

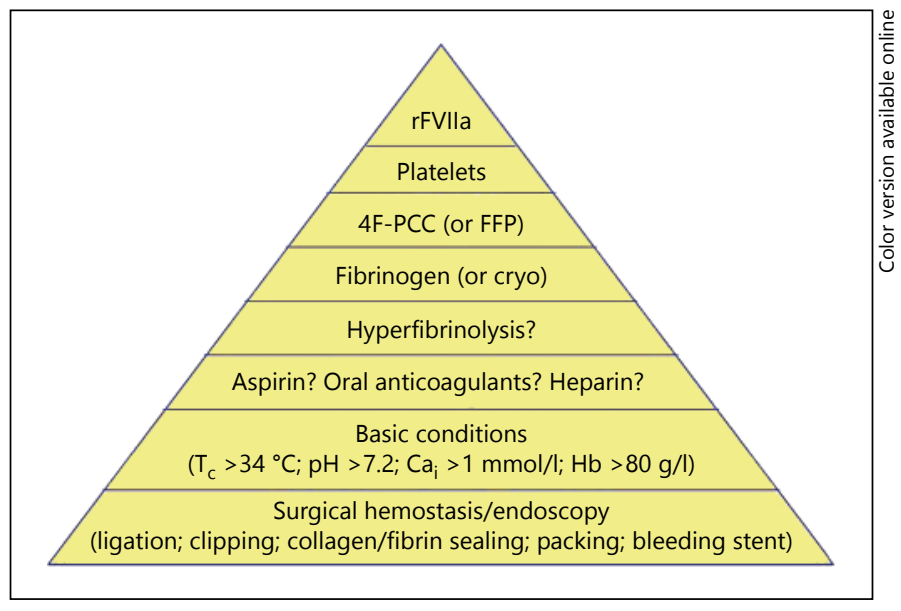

Fig. 5. Pyramid of hemostatic therapy in patients with ESLD. Note that therapy should always be started from the pyramid's basis rather than from its top. $\mathrm{Ca}_{\mathrm{i}}=$ Ionized calcium; Cryo $=$ cryoprecipitate; fibrinogen $=$ fibrinogen concentrate; $4 \mathrm{~F}-\mathrm{PCC}=$ four-factor PCC; $\mathrm{Hb}=$ hemoglobin; $\mathrm{T}_{\mathrm{c}}=$ core temperature.

Table 1. ROTEM ${ }^{\mathrm{TM}}$ (FIBTEM ${ }^{\mathrm{TM}}$ )-based calculation of fibrinogen dosage in patients with normovolemia and a $\mathrm{Hb}$ concentration of about $10 \mathrm{~g} / \mathrm{dl}$

\begin{tabular}{lll}
\hline $\begin{array}{l}\text { Targeted increase } \\
\text { in } \mathrm{MCF}_{\mathrm{FIB}}, \mathrm{mm}\end{array}$ & $\begin{array}{l}\text { Dosage, } \\
\mathrm{mg} / \mathrm{kg} \text { b.w. }\end{array}$ & $\begin{array}{l}\text { Dosage, } \\
\mathrm{g} / 80 \mathrm{~kg} \mathrm{b.w.}\end{array}$ \\
\hline 4 & 25 & 2 \\
8 & 50 & 4 \\
12 & 75 & 6 \\
16 & 100 & 8 \\
\hline
\end{tabular}

In case of hypervolemia, $\mathrm{Hb}<10 \mathrm{~g} / \mathrm{l}$ and/or severe bleeding, the actual increase may be lower than calculated. Only sparse data exist for patients with body weights of $<20$ or $>80 \mathrm{~kg}$, respectively [modified after 90].

tion parameters such as the PT and aPTT remain within normal limits even in patients with a severe factor XIII deficiency. Factor XIII deficiency can only be detected by measuring the factor itself. Patients with a regular ROTEM pattern, platelets and serum fibrinogen within the normal range but still bleeding, should undergo factor XIII assessment, to exclude a factor XIII deficiency. Treatment in some European countries consists of administration of a purified factor XIII concentrate (Fibrogammin ${ }^{\mathrm{TM}}$; CSL Behring $\mathrm{GmbH}$ ) or cryoprecipitate administration, which is not approved in Germany due to the high risk of viral transmission. 
In contrast to vitamin $\mathrm{K}$-dependent coagulation factors, factor XIII activity remains at a normal level in stable cirrhotic patients [78]. However, patients in a 6-year follow-up had a significantly increased risk of upper gastrointestinal bleeding if factor XIII activity was $<50 \%$ [78].

\section{Thromboprophylaxis in Patients with Liver Cirrhosis}

PT, aPTT and INR do not predict bleeding risk in cirrhotic patients [21]. A prolonged aPTT or increased INR does not indicate auto-anticoagulation in patients' liver disease [79]. A prolonged aPTT could be caused by a factor XII deficiency, which is associated with thrombosis rather than bleeding [80]. A literature review indicates a $0.5-8.2 \%$ incidence of venous thromboembolism in cirrhotic patients [79]. The authors stated that in hospitalized cirrhotic patients, venous thromboembolism should be strongly considered if there is no active bleeding.

In a recent study the use of low molecular weight heparin was evaluated for the prevention of portal vein thrombosis [81]. A total of 70 outpatients were recruited in the study. The median MELD score was 13 in both groups. The intervention group received $40 \mathrm{mg}(4,000 \mathrm{IU}$ anti-Xa) enoxaparin SQ. Patients with hepatocellular carcinoma were excluded. At 1 year, $27.7 \%$ in the no-treatment group developed portal vein thrombosis versus $0 \%$ in the enoxaparin group. Bleeding episodes in the enoxaparin group were not reported to be higher.

Patients with cirrhosis appear to have a lower anti-Xa activity level with a negative correlation with liver function, which may affect the monitoring of enoxaparin [82].

\section{Thrombopoietin Receptor Agonist during Hepatitis C Treatment}

Hematological side effects such as leuko- or thrombocytopenia limits the use of peginterferon- $\alpha$ (PegIFN- $\alpha$ )based hepatitis $C$ antiviral treatment [83], which is one of the reasons to stop the antiviral treatment or to lower the dose [84]. Thrombopoietin receptor agonists such as romiplastin or eltrombopag $[85,86]$ can be used for raising the platelet count before or during antiviral treatment with an IFN- $\alpha$-based protocol. Patients with advanced liver disease may benefit more from thrombopoietin receptor agonist treatment because of a more pronounced thrombocytopenia. This issue is underscored by the study of Heathcote et al. [87]. They reported a 19\% incidence of severe thrombocytopenia in cirrhotic patients during PegIFN- $\alpha$.
The thrombopoietin receptor agonist eltrombopag was evaluated in a prospective randomized, placebo-controlled trial [88]. $74 \mathrm{HCV}$ patients were recruited for this study receiving a PegIFN- $\alpha$-based antiviral treatment. Patients with platelet counts between 20 and $70 / \mathrm{nl}$ were assigned to receive eltrompag in three different doses or placebo. Platelet counts in all eltrompag arms were significantly higher compared to placebo.

Tripodi and Primignani [89] reported very recently about successful eltrompag treatment in cirrhotic patients to increase their platelet count. Patients with chronic liver disease and a platelet count $\leq 50 / \mathrm{nl}$ received $75 \mathrm{mg}$ eltrombopag orally. The endpoint was avoidance of platelet transfusion before an elective intervention. In $72 \%$ of the eltrompag group, a platelet transfusion could be avoided compared to the placebo group $(19 \%, \mathrm{p}<0.001)$. However, 6 patients in the eltrompag group developed portal vein thrombosis compared to only 1 patient in the placebo arm, which resulted in the termination of the study.

\section{Point-of-Care-Based Coagulation Management in Liver Transplantation}

In a retrospective study, we demonstrated that the implementation of a point-of-care-based coagulation management algorithm (fig. 3) was effective in reducing allogeneic blood transfusion requirements [9]. During an observational period of 10 years (1999-2009), the requirements for RBC transfusion in visceral surgery, including liver transplantation, could be reduced by $60 \%$, for FFP by $89 \%$, and for platelet transfusion by $58 \%$, respectively, despite an increase in liver transplants per year by approximately $47 \%$ (97-143/year). Within the same period of time, the overall expenses for blood products and coagulation factor concentrates were significantly reduced. In 2010, the median transfusion requirements for RBCs were 2 units $(0 ; 4 \mathrm{U})$ median (25th; 75th percentile). Massive transfusion ( $\geq 10 \mathrm{U}$ RBCs, intraoperatively) was necessary in $7.4 \%(12 / 162)$ of all patients undergoing liver transplantation [unpubl. data]. Median transfusion requirements for both FFP and platelet concentrates were 0 units $(0 ; 0) .65,83$ and $80 \%$ of all liver transplants could be performed without any RBC, FFP or platelet transfusions, respectively. Off-label use of rFVIIa was not necessary in any of the cases. In 2009 and 2010 , the incidence of composite thrombotic/thromboembolic events (hepatic artery thrombosis, portal vein thrombosis, pulmonary embolism, myocardial ischemia, and stroke) was $6.25 \%(16 / 256)$ [48]. 


\section{Conclusion}

Blood transfusion or, even more so, platelet transfusion, are associated with increased morbidity and mortality in patients undergoing liver transplantation. Any prophylactic platelet or allogeneic blood transfusions due to pathologic laboratory results should thus be strictly avoided. On the other hand, first-line therapy with fibrinogen and PCC as guided by thromboelastometry in bleeding patients with ESLD is associated with decreased blood transfusion requirements and hospital costs in this clinical setting. Nevertheless, further studies will have to confirm that this approach also results in improved outcomes in the patients.

\section{References}

1 Starzl TE, Iwatsuki S, Van Thiel DH, Gartner JC, Zitelli BJ, Malatack JJ, Schade RR, Shaw BW Jr, Hakala TR, Rosenthal JT, Porter KA: Evolution of liver transplantation. Hepatology 1982;2:614-636.

2 Dara SI, Rana R, Afessa B, Moore SB, Gajic O: Fresh frozen plasma transfusion in critically ill medical patients with coagulopathy. Crit Care Med 2005;33:2667-2671.

3 Khan H, Belsher J, Yilmaz M, Afessa B, Winters JL, Moore SB, Hubmayr RD, Gajic O: Fresh frozen plasma and platelet transfusions are associated with development of acute lung injury in critically ill medical patients. Chest 2007;131:1308-1314.

4 Pereboom IT, de Boer MT, Haagsma EB, Hendriks HG, Lisman T, Porte RJ: Platelet transfusion during liver transplantation is associated with increased postoperative mortality due to acute lung injury. Anesth Analg 2009;108:1083-1091.

5 Sarani B, Dunkman WJ, Dean L, Sonnad S, Rohrbach JI, Gracias VH: Transfusion of fresh frozen plasma in critically ill surgical patients is associated with an increased risk of infection. Crit Care Med 2008;36:1114-1118.

6 Groenland TH, Porte RJ, Bakker CM, Stibbe $\mathrm{J}$ : Hemostasis in heterotopic liver transplantation. Semin Thromb Hemost 1993;19:213217.

7 Porte RJ: Coagulation and fibrinolysis in orthotopic liver transplantation: current views and insights. Semin Thromb Hemost 1993; 19:191-196.

8 Gorlinger K, Dirkmann D, Hanke AA, Kamler M, Kottenberg E, Thielmann M, Jakob H, Peters J: First-line therapy with coagulation factor concentrates combined with point-ofcare coagulation testing is associated with decreased allogeneic blood transfusion in cardiovascular surgery: a retrospective, singlecenter cohort study. Anesthesiology 2011; 115:1179-1191.

9 Gorlinger K, Dirkmann D, Müller-Beissenhirtz H, Paul A, Hartmann M, Saner F: Thromboelastometry-based perioperative coagulation management in visceral surgery and liver transplantation: experience of 10 years and 1105 LTX. Liver Transpl 2010; 16:S86.

10 Northup PG, Sundaram V, Fallon MB, Reddy KR, Balogun RA, Sanyal AJ, Anstee QM,
Hoffman MR, Ikura Y, Caldwell SH: Hypercoagulation and thrombophilia in liver disease. J Thromb Haemost 2008;6:2-9.

11 Hugenholtz GC, Adelmeijer J, Meijers JC, Porte RJ, Stravitz RT, Lisman T: An unbalance between von Willebrand factor and ADAMTS13 in acute liver failure: implications for hemostasis and clinical outcome. Hepatology 2013;58:752-761.

12 Lisman T, Porte RJ: Rebalanced hemostasis in patients with liver disease: evidence and clinical consequences. Blood 2010;116:878885.

13 Lisman T, Bongers TN, Adelmeijer J, Janssen HL, de Maat MP, de Groot PG, Leebeek FW: Elevated levels of von Willebrand factor in cirrhosis support platelet adhesion despite reduced functional capacity. Hepatology 2006; 44:53-61.

14 Hollestelle MJ, Geertzen HG, Straatsburg IH, van Gulik TM, van Mourik JA: Factor VIII expression in liver disease. Thromb Haemost 2004;91:267-275.

15 Francis JL, Armstrong DJ: Fibrinogenbound sialic acid levels in the dysfibrinogenaemia of liver disease. Haemostasis 1982;11: 215-222.

16 Oksuzoglu G, Simsek H, Haznedaroglu IC, Kirazli S: Tissue factor pathway inhibitor concentrations in cirrhotic patients with and without portal vein thrombosis. Am J Gastroenterol 1997;92:303-306.

17 Leebeek FW, Kluft C, Knot EA, de Maat MP, Wilson JH: A shift in balance between profibrinolytic and antifibrinolytic factors causes enhanced fibrinolysis in cirrhosis. Gastroenterology 1991;101:1382-1390.

18 Violi F, Leo R, Basili S, Ferro D, Cordova C, Balsano F: Association between prolonged bleeding time and gastrointestinal hemorrhage in 102 patients with liver cirrhosis: results of a retrospective study. Haematologica 1994;79:61-65.

19 Ferro D, Celestini A, Violi F: Hyperfibrinolysis in liver disease. Clin Liver Dis 2009;13: 21-31.

20 Gorlinger K: Coagulation management during liver transplantation (in German). Hamostaseologie 2006;26:S64-S76.

21 Tripodi A, Mannucci PM: The coagulopathy of chronic liver disease. N Engl J Med 2011; 365:147-156.
22 Tripodi A, Salerno F, Chantarangkul V, Clerici M, Cazzaniga M, Primignani M, Mannuccio Mannucci P: Evidence of normal thrombin generation in cirrhosis despite abnormal conventional coagulation tests. Hepatology 2005;41:553-558.

23 Tripodi A, Primignani M, Chantarangkul V, Dell'Era A, Clerici M, de Franchis R, Colombo M, Mannucci PM: An imbalance of provs. anti-coagulation factors in plasma from patients with cirrhosis. Gastroenterology 2009;137:2105-2111.

24 Ben-Ari Z, Panagou M, Patch D, Bates S, Osman E, Pasi J, Burroughs A: Hypercoagulability in patients with primary biliary cirrhosis and primary sclerosing cholangitis evaluated by thrombelastography. J Hepatol 1997;26: 554-559.

25 Lang T, Johanning K, Metzler H, Piepenbrock S, Solomon C, Rahe-Meyer N, Tanaka KA: The effects of fibrinogen levels on thromboelastometric variables in the presence of thrombocytopenia. Anesth Analg 2009;108: 751-758.

26 Lisman T, Porte RJ, Leebeek FW, Caldwell $\mathrm{SH}$ : Methodological issues with coagulation testing in patients with liver disease. J Thromb Haemost 2006;4:2061-2062.

27 Tripodi A: Tests of coagulation in liver disease. Clin Liver Dis 2009;13:55-61.

28 Lang T, von Depka M: Possibilities and limitations of thrombelastometry/-graphy (in German). Hamostaseologie 2006;26:S20-S29.

29 Kashuk JL, Moore EE, Sabel A, Barnett C, Haenel J, Le T, Pezold M, Lawrence J, Biffl WL, Cothren CC, Johnson JL: Rapid thrombelastography (r-TEG) identifies hypercoagulability and predicts thromboembolic events in surgical patients. Surgery 2009;146:764772; discussion 772-764.

30 McCrath DJ, Cerboni E, Frumento RJ, Hirsh AL, Bennett-Guerrero E: Thromboelastography maximum amplitude predicts postoperative thrombotic complications including myocardial infarction. Anesth Analg 2005; 100:1576-1583.

31 Rahe-Meyer N, Winterhalter M, Boden A, Froemke C, Piepenbrock S, Calatzis A, Solomon C: Platelet concentrates transfusion in cardiac surgery and platelet function assessment by multiple electrode aggregometry. Acta Anaesthesiol Scand 2009;53:168-175. 
32 Toth O, Calatzis A, Penz S, Losonczy H, Siess $\mathrm{W}$ : Multiple electrode aggregometry: a new device to measure platelet aggregation in whole blood. Thromb Haemost 2006;96:781-788.

33 Hanke AA, Roberg K, Monaca E, Sellmann T, Weber CF, Rahe-Meyer N, Gorlinger K: Impact of platelet count on results obtained from multiple electrode platelet aggregometry (Multiplate). Eur J Med Res 2010;15:214-219.

34 Blonski W, Siropaides T, Reddy KR: Coagulopathy in liver disease. Curr Treat Options Gastroenterol 2007;10:464-473.

35 De Gasperi A, Corti A, Mazza E, Prosperi M, Amici O, Bettinelli L: Acute liver failure: managing coagulopathy and the bleeding diathesis. Transplant Proc 2009;41:1256-1259.

36 Lisman T, Bakhtiari K, Pereboom IT, Hendriks HG, Meijers JC, Porte RJ: Normal to increased thrombin generation in patients undergoing liver transplantation despite prolonged conventional coagulation tests. J Hepatol 2010;52:355-361.

37 Hellstern P: Solvent/detergent-treated plasma: composition, efficacy, and safety. Curr Opin Hematol 2004;11:346-350.

38 De Jonge J, Groenland TH, Metselaar HJ, IJzermans JN, van Vliet HH, Visser L, Tilanus HW: Fibrinolysis during liver transplantation is enhanced by using solvent/detergent virusinactivated plasma (ESDEP). Anesth Analg 2002;94:1127-1131.

39 Depasse F, Sensebe L, Seghatchian J, Andreu G, Samama MM: The influence of methylene blue light treatment and methylene blue removal filter on fibrinogen activity states and fibrin polymerisation indices. Transfus Apher Sci 2005;33:63-69.

40 Dara SI, Rana R, Afessa B, Moore SB, Gajic O: Fresh frozen plasma transfusion in critically ill medical patients with coagulopathy. Crit Care Med 2005;33:2667-2671.

41 Hatano E, Terajima H, Yabe S, Asonuma K, Egawa H, Kiuchi T, Uemoto S, Inomata Y, Tanaka K, Yamaoka Y: Hepatic artery thrombosis in living related liver transplantation. Transplantation 1997;64:1443-1446.

42 Sarani B, Dunkman WJ, Dean L, Sonnad S, Rohrbach JI, Gracias VH: Transfusion of fresh frozen plasma in critically ill surgical patients is associated with an increased risk of infection. Crit Care Med 2008;36:1114-1118.

43 Keller-Stanislawski B, Reil A, Gunay S, Funk MB: Frequency and severity of transfusionrelated acute lung injury - German haemovigilance data (2006-2007). Vox Sang 2010;98: 70-77.

44 Stanworth SJ: The evidence-based use of FFP and cryoprecipitate for abnormalities of coagulation tests and clinical coagulopathy. Hematology Am Soc Hematol Educ Prog 2007: 179-186.

45 Lorenz R, Kienast J, Otto U, Egger K, Kiehl M, Schreiter D, Kwasny H, Haertel S, Barthels M: Efficacy and safety of a prothrombin complex concentrate with two virus-inactivation steps in patients with severe liver damage. Eur J Gastroenterol Hepatol 2003;15:15-20.
46 Scherer R, Gille A, Erhard J, Paar D, Kox WJ: The effect of substitution with AT III- and PPSB concentrates in patients with terminal liver insufficiency (in German). Anaesthesist 1994;43:178-182.

47 Sakai T, Matsusaki T, Dai F, Tanaka KA, Donaldson JB, Hilmi IA, Wallis Marsh J, Planinsic RM, Humar A: Pulmonary thromboembolism during adult liver transplantation: incidence, clinical presentation, outcome, risk factors, and diagnostic predictors. Br J Anaesth 2012;108:469-477.

48 Kirchner C, Goerlinger K, Dirkmann D, Schumann R, Treckmann J, Paul A, Saner FH: Safety and efficacy of prothrombin complex and fibrinogen concentrates in liver transplantation. Liver Transplant 2012;18:S189.

49 Levy JH, Fingerhut A, Brott T, Langbakke IH, Erhardtsen E, Porte RJ: Recombinant factor VIIa in patients with coagulopathy secondary to anticoagulant therapy, cirrhosis, or severe traumatic injury: review of safety profile. Transfusion 2006;46:919-933.

50 Lodge JP, Jonas S, Jones RM, Olausson M, Mir-Pallardo J, Soefelt S, Garcia-Valdecasas JC, McAlister V, Mirza DF: Efficacy and safety of repeated perioperative doses of recombinant factor VIIa in liver transplantation. Liver Transpl 2005;11:973-979.

51 Planinsic RM, van der Meer J, Testa G, Grande L, Candela A, Porte RJ, Ghobrial RM, Isoniemi H, Schelde PB, Erhardtsen E, Klintmalm G, Emre S: Safety and efficacy of a single bolus administration of recombinant factor VIIa in liver transplantation due to chronic liver disease. Liver Transpl 2005; 11: 895-900.

52 Porte RJ, Knot EA, Bontempo FA: Hemostasis in liver transplantation. Gastroenterology 1989;97:488-501.

53 Findlay JY, Rettke SR, Ereth MH, Plevak DJ, Krom RA, Kufner RP: Aprotinin reduces red blood cell transfusion in orthotopic liver transplantation: a prospective, randomized, double-blind study. Liver Transpl 2001;7: 802-807.

54 Molenaar IQ, Warnaar N, Groen H, Tenvergert EM, Slooff MJ, Porte RJ: Efficacy and safety of antifibrinolytic drugs in liver transplantation: a systematic review and metaanalysis. Am J Transplant 2007;7:185-194.

55 Ramsay MA: Con: Antifibrinolytics are not safe and effective in patients undergoing liver transplantation. J Cardiothorac Vasc Anesth 2006:20:891-893.

56 Mangano DT, Rieves RD, Weiss KD: Judging the safety of aprotinin. N Engl J Med 2006; 355:2261-2262.

57 Mangano DT, Tudor IC, Dietzel C: The risk associated with aprotinin in cardiac surgery. N Engl J Med 2006;354:353-365.

58 Warnaar N, Mallett SV, de Boer MT, Rolando N, Burroughs AK, Nijsten MW, Slooff MJ, Rolles K, Porte RJ: The impact of aprotinin on renal function after liver transplantation: an analysis of 1,043 patients. Am J Transplant 2007;7:2378-2387.
59 European Medicines Agency recommends lifting suspension of aprotinin. 2012.

60 Fergusson DA, Hebert PC, Mazer CD, Fremes S, MacAdams C, Murkin JM, Teoh K, Duke PC, Arellano R, Blajchman MA, Bussieres JS, Cote D, Karski J, Martineau R, Robblee JA, Rodger M, Wells G, Clinch J, Pretorius R: A comparison of aprotinin and lysine analogues in high-risk cardiac surgery. $\mathrm{N}$ Engl J Med 2008;358:2319-2331.

61 Porte RJ, Leebeek FW: Pharmacological strategies to decrease transfusion requirements in patients undergoing surgery. Drugs 2002;62: 2193-2211.

62 Giovannini I, Chiarla C, Giuliante F, Vellone M, Nuzzo G: Modulation of plasma fibrinogen levels in acute-phase response after hepatectomy. Clin Chem Lab Med 2004;42:261-265.

63 Caldwell SH, Sanyal AJ: Coagulation disorders and bleeding in liver disease: future directions. Clin Liver Dis 2009;13:155-157.

64 Fenger-Eriksen C, Tonnesen E, Ingerslev J, Sorensen B: Mechanisms of hydroxyethyl starch-induced dilutional coagulopathy. J Thromb Haemost 2009;7:1099-1105.

65 Fries D: Dilutional coagulopathy: development, diagnostic options and management (in German). Hamostaseologie 2006;26:S15-S19.

66 Hiippala ST: Dextran and hydroxyethyl starch interfere with fibrinogen assays. Blood Coagul Fibrinolysis 1995;6:743-746.

67 Danes AF, Cuenca LG, Bueno SR, Mendarte Barrenechea L, Ronsano JB: Efficacy and tolerability of human fibrinogen concentrate administration to patients with acquired fibrinogen deficiency and active or in high-risk severe bleeding. Vox Sang 2008;94:221-226.

68 Fenger-Eriksen C, Ingerslev J, Sorensen B: Fibrinogen concentrate - a potential universal hemostatic agent. Expert Opin Biol Ther 2009;9:1325-1333.

69 Weinkove R, Rangarajan S: Fibrinogen concentrate for acquired hypofibrinogenaemic states. Transfus Med 2008;18:151-157.

70 Gorlinger K: Differenzierte Therapie komplexer Gerinnungsstörungen. J Anaesth Intensivbeh 2005;12:120-124.

71 Rahe-Meyer N, Solomon C, Winterhalter M, Piepenbrock S, Tanaka K, Haverich A, Pichlmaier M: Thromboelastometry-guided administration of fibrinogen concentrate for the treatment of excessive intraoperative bleeding in thoracoabdominal aortic aneurysm surgery. J Thorac Cardiovasc Surg 2009;138:694-702.

72 De Boer MT, Christensen MC, Asmussen M, van der Hilst CS, Hendriks HG, Slooff MJ, Porte RJ: The impact of intraoperative transfusion of platelets and red blood cells on survival after liver transplantation. Anesth Analg 2008;106:32-44.

73 Burger R, Offergeld R: Festlegung der Haltbarkeitsfrist von Thrombozytenkonzentraten mit dem Ziel der Reduktion lebensbedrohlicher septischer Transfusionsreaktionen durch bakterielle Kontamination. Bundesgesundheitsblatt Gesundheitsforsch Gesundheitsschutz 2008;51:1484. 
74 Hsieh L, Nugent D: Factor XIII deficiency. Haemophilia 2008;14:1190-1200.

75 Peyvandi F, Palla R, Menegatti M, Mannucci PM: Rare bleeding disorders: general aspects of clinical features, diagnosis, and management. Semin Thromb Hemost 2009;35:349355.

76 Wettstein P, Haeberli A, Stutz M, Rohner M, Corbetta C, Gabi K, Schnider T, Korte W: Decreased factor XIII availability for thrombin and early loss of clot firmness in patients with unexplained intraoperative bleeding. Anesth Analg 2004;99:1564-1569.

77 Gerlach R, Tolle F, Raabe A, Zimmermann M, Siegemund A, Seifert V: Increased risk for postoperative hemorrhage after intracranial surgery in patients with decreased factor XIII activity: implications of a prospective study. Stroke 2002;33:1618-1623.

78 Tacke F, Fiedler K, von Depka M, Luedde T, Hecker H, Manns MP, Ganser A, Trautwein $\mathrm{C}$ : Clinical and prognostic role of plasma coagulation factor XIII activity for bleeding disorders and 6-year survival in patients with chronic liver disease. Liver Int 2006;26:173181.

79 Koliscak L, Maynor L: Pharmacologic prophylaxis against venous thromboembolism in hospitalized patients with cirrhosis and associated coagulopathies. Am J Health Syst Pharm 2012;69:658-663.

80 Renne T, Schmaier AH, Nickel KF, Blomback $\mathrm{M}$, Maas C: In vivo roles of factor XII. Blood 2012;120:4296-4303.
81 Villa E, Camma C, Marietta M, Luongo M, Critelli R, Colopi S, Tata C, Zecchini R, Gitto S, Petta S, Lei B, Bernabucci V, Vukotic R, De Maria N, Schepis F, Karampatou A, Caporali C, Simoni L, Del Buono M, Zambotto B, Turola E, Fornaciari G, Schianchi S, Ferrari A, Valla D: Enoxaparin prevents portal vein thrombosis and liver decompensation in patients with advanced cirrhosis. Gastroenterology 2012;143:1253-1260, e1251-e1254.

82 Bechmann LP, Sichau M, Wichert M, Gerken G, Kroger K, Hilgard P: Low-molecularweight heparin in patients with advanced cirrhosis. Liver Int 2011;31:75-82.

83 Mira JA, Lopez-Cortes LF, Merino D, Arizcorreta-Yarza A, Rivero A, Collado A, Rios-Villegas MJ, Gonzalez-Serrano M, Torres-Tortoso M, Macias J, Valera-Bestard B, FernandezFuertes E, Giron-Gonzalez JA, Lozano F, Pineda JA: Predictors of severe haematological toxicity secondary to pegylated interferon plus ribavirin treatment in HIV-HCV-coinfected patients. Antivir Ther 2007;12:12251235.

84 McHutchison JG, Manns M, Patel K, Poynard T, Lindsay KL, Trepo C, Dienstag J, Lee WM, Mak C, Garaud JJ, Albrecht JK: Adherence to combination therapy enhances sustained response in genotype-1-infected patients with chronic hepatitis C. Gastroenterology 2002; 123:1061-1069.

85 Saleh MN, Bussel JB, Cheng G, Meyer O, Bailey CK, Arning M, Brainsky A: Safety and efficacy of eltrombopag for treatment of chronic immune thrombocytopenia: results of the long-term, open-label extend study. Blood 2013;121:537-545.
86 Kuter DJ, Bussel JB, Lyons RM, Pullarkat V, Gernsheimer TB, Senecal FM, Aledort LM, George JN, Kessler CM, Sanz MA, Liebman HA, Slovick FT, de Wolf JT, Bourgeois E, Guthrie TH Jr, Newland A, Wasser JS, Hamburg SI, Grande C, Lefrere F, Lichtin AE, Tarantino MD, Terebelo HR, Viallard JF, Cuevas FJ, Go RS, Henry DH, Redner RL, Rice L, Schipperus MR, Guo DM, Nichol JL: Efficacy of romiplostim in patients with chronic immune thrombocytopenic purpura: a doubleblind randomised controlled trial. Lancet 2008;371:395-403.

87 Heathcote EJ, Shiffman ML, Cooksley WG, Dusheiko GM, Lee SS, Balart L, Reindollar R, Reddy RK, Wright TL, Lin A, Hoffman J, De Pamphilis J: Peginterferon alfa-2a in patients with chronic hepatitis $\mathrm{C}$ and cirrhosis. $\mathrm{N}$ Engl J Med 2000;343:1673-1680.

88 McHutchison JG, Dusheiko G, Shiffman ML, Rodriguez-Torres M, Sigal S, Bourliere M, Berg T, Gordon SC, Campbell FM, Theodore D, Blackman N, Jenkins J, Afdhal NH: Eltrombopag for thrombocytopenia in patients with cirrhosis associated with hepatitis C. N Engl J Med 2007;357:2227-2236.

89 Tripodi A, Primignani M: Non-transfusional approach to increase platelet count in patients with cirrhosis and thrombocytopenia. Hepatology 2013, E-pub ahead of print.

90 Lier H, Vorweg M, Hanke A, Gorlinger K: Thromboelastometry guided therapy of severe bleeding. Essener Runde algorithm. Hamostaseologie 2013;33:51-61. 